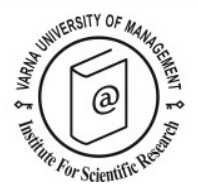

\title{
The protected areas: are they still in the 'pleasure periphery' or are they destinations for sustainable tourism activities?
}

\author{
Josef Navrátil $^{1 *}$, Jaroslav Knotek ${ }^{2}$, Kamil Pícha ${ }^{3}$ and Jitka Fialová ${ }^{4}$
}

Received: 26/11/2014 Accepted: 31/05/2015

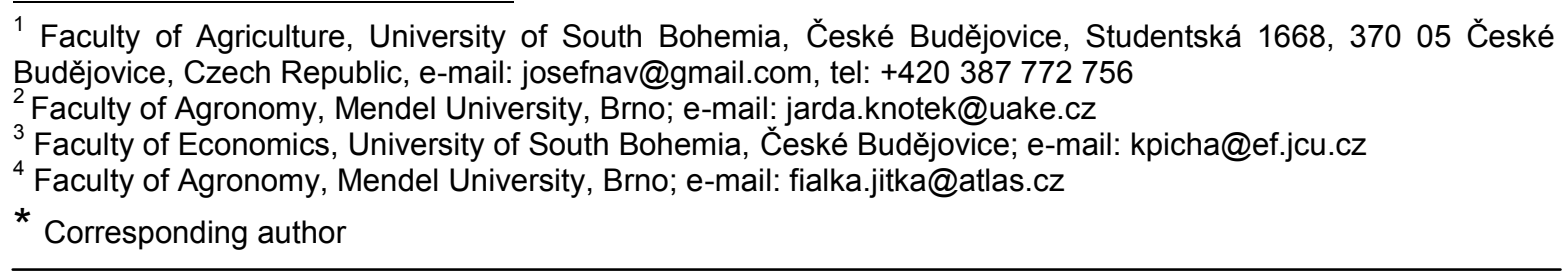

\section{Abstract}

The protected natural areas play an important role in recreation. This paper discusses the issue of recreational activities in these areas. The National Park and Protected Landscape Areas in the southern part of the Czech Republic were selected for the purposes of illustration. It has been revealed that relaxation is the most important activity among tourists in the large-area protected natural territories, according to a recent survey of 1,500 participants. Entertainment is the second most important activity. Recreational sport activities (such as swimming, tennis, etc.) are respectively in the third and fourth places. We can talk about the large-area protected natural reservations as destinations for "nature-based tourism", whose prerequisite is the existence of a pristine natural environment, which is primarily bound to protected natural areas in today's world, and it is not for sustainable tourism. According to the participation in recreation activities, four segments of demand have been identified in visits to these large-area protected natural territories: (1) passive visitors, (2) visitors focused on exploring but not participating in any physical activity, (3) active visitors with a dominant interest in bicycle touring, and (4) active visitors with a dominant interest in history.

(C) 2015 Varna University of Management. All rights reserved

Keywords: tourists, ecotourism, behaviour, national park, the Czech Republic

Citation: Navrátil J., J. Knotek, K. Pícha and J. Fialová (2015) The protected areas: are they still in the 'pleasure periphery' or are they destinations for sustainable tourism activities? European Journal of Tourism Research 11, pp. 57-72

\section{Introduction}

The pleasure periphery (in the sense of the wilderness and national parks according to Hall and Page, 2006) belongs to the most important spaces for recreation and tourism (Newsome et al., 2013). These two activities "have increasingly become significant as one of the main values attached to the wilderness and its 
conservation" (Hall and Page 2006: 278). The possibility of developing recreational activities is among the main motives for creating national parks (Williams, 2000) and tourism remains an important justification for park creation and its development even today (Hall and Lew, 2009). Similarly to the rural environment (Kayat, 2008; Santana-Jiménez, Hernández, and SuárezVega, 2013), these spaces particularly offer the opportunity of regenerating those people living in urban spaces, who have no possibility of every day contact with the "environment of nature" (Olwig and Olwig, 1979).

The management of the protected areas must meet two contradictory requirements: to contribute to minimising the human impact on its environment and to make it accessible to visitors (Marion and Reid, 2007). Tourism activities themselves provide considerable benefits to the protected areas but these same activities can contribute to the deterioration of landscapes, threaten biodiversity, and contribute to degradation of the ecosystems, too (Bushell and McCool, 2007). That is why conflicts between conservational and touristic uses of the protected areas usually occur (Young et al., 2007). Thus, tourists (as the main visitors to such environments) are the keystones of the appropriate planning management of the protected areas (Ogonowska and Torre, 2013) and elsewhere (Borges et al., 2014).

Environmentally-friendly activities done by visitors are supported by the management of the protected areas to prevent disagreements and to enhance the responsible behaviour of tourists (Leslie, 2012; Nicholls and Kang, 2012). Educating visitors (Munro et al., 2008; Leung, 2012; Tomljenović and Kunst, 2014) and increasing their environmental awareness (Ballantyne et al., 2011) seem to be of crucial importance. A whole range of activities, (such as publications and websites, electronic educational resources, visitor centres, selfguided trails, and guided tours) are included (Newsome et al., 2013). The protected areas should become important destinations for sustainable tourism activities.

This change was initiated many years ago in Western countries (Newsome et al., 2013).
However, it has spread out even to developing countries (Lourens, 2007), as well as into the Central and Eastern European countries (Cetkovsky et al., 2007; Foret and Klusacek, 2011; Svec et al., 2012; Frantal and Urbankova, 2014; Kroupova et al., 2014; Bernat, 2014). A large amount of money is spent on work with tourists in the Czech Republic, particularly when it comes to environmental education. Those activities are principally concentrated in the national parks and the protected landscape areas, especially in the areas involved in the UNESCO Man and the Biosphere Programme. These protected areas represent an important percentage of the area of South Bohemia and there are two important MAB areas in this region: The Šumava area and the Treboň Basin. South Bohemia was chosen as a study area for this reason.

The aim of this paper is to assess if protected areas are destinations for sustainable tourism activities or rather still in the "pleasure periphery". We have stated two objectives to fulfil the aim:

1. To compare the extent of the visitors' participation in individual activities within the protected areas to those activities that are performed in the larger tourist region as a whole.

2. To identify the types of visitors to the protected areas based on their main behavioural activities that are practised during the visit to the protected areas.

The research questions we would like to address are:

- What tourism activities are practiced more often than others?

- Which tourism activities are different among these visitors of the protected areas and visitors of the tourist region?

- Which tourism activities are usually practiced together?

- Can the reasonable types of visitors to the protected areas be defined based on the degree of participation in the recreational activities?

\section{Tourism in the protected areas}

The original idea of protecting ecosystems and landscapes through the national park concept 
was born in order to protect the possibility for recreational activities outside of an urban space, situating them in "public parks" (Frost and Hall, 2009), followed by chateau gardens (Mark, 2009). These places were of high natural and cultural value in most cases (Hall and Frost, 2009a). Even though tourism has played an important role in protecting such places from destructive economic pressures (Hall and Frost, 2009b), conflicts concerning protection and the acceptability of tourism activities are among the severest to deal with (Hall and Lew, 2009). These areas are unique in their ecosystems, landscapes, and also in the possibilities they present for spending free time outside of the everyday urban environment (Balmford et al., 2009). Here it is important to note that the recreational function of the national parks and the protected landscape areas is one of the important protection aims under the IUCN protected area categories (IUCN, 2014). Combining ecosystem and landscape protection (which usually goes hand-in-hand with the protection of species and habitats) with tourism activities (and especially with its side-effects) presents a complicated global problem nowadays (e.g., Fredman and Sandell, 2009).

The progressive degradation of the environment and its urbanization further increase the value of the "pleasure periphery" in tourism (Bushell et al., 2007). Then those kinds of environment are more and more exposed to the pressure resulting from the conflicts among different types of use (Jamal et al., 2002; McClanahan et al., 2009). The real risk of degradation in tourism increases with the rising number of tourists (Geneletti and Dawa, 2009; Marion and Leung 2001; Vasiljević et al. 2011).

Thus, new concepts of tourism are gradually being developed and they usually have one thing in common which is the search for an answer to the following question: "How can tourism be developed in individual areas without negatively affecting the areas and their local communities?" (Holden, 2000; Hall and Lew, 2009). It includes those concepts based on the framework for the consumption of "green" products (Nicholls and Kang, 2012). Each concept is often defined by its author, and each of them can be distinguished from the other concepts, according to the importance placed on minimizing the negative impacts and/or on maximizing the positive impacts, the influences on the environment and/or the community, on preserving the resources, on maintaining growth, etc. We often come across the following terms: ecotourism, sustainable tourism, green tourism, soft tourism, alternative tourism, ethnic tourism, or cultural tourism (Leslie, 2012). Although they encompass a lot of "defined" aspects, they mainly concern an approach to the behaviour in tourism (Spenceley, 2008; Lee et al., 2013), on both the supply and the demand side. Maybe the best description has been stated by Leslie (2012: 1):

"The use of the term , 'responsible' in this context implies being responsible for', implying that those involved in tourism are responsible for the consequences of tourism as an activity."

The activities of travellers that have caused the degradation of the environment are of the most importance (among other aspects) regarding the demand side. First of all, the pleasure periphery used to being the destination of nature based tourism. Under the latter notion, it is understood that tourism is determined by the existence of the "natural" environment, i.e. primarily the protected areas of landscape and particularly the national parks. Then tourism is induced by the motivation of people to have a pleasant experience from a stay in an intact environment (Weiler and Davis, 1993). It concerns all types of tourism, where the activities are related to the natural environment, including the mass forms. Although the conservational importance of nature-based tourism is accentuated sometimes, as a matter of fact, this tourism has no such effect (Kline, 2001). Environmental friendly tourism, such as ecotourism, differs from the classic naturebased tourism, particularly in the conservationist aspect, when the participant of the environmental-friendly tourism turns from the passive visitor to the active contributor to the sustainable use of the tourist attractions (Sjøholt, 2000). Other important elements of ecotourism are the condition to use tourist sources in a way that is favorable to the local inhabitants (Epler Wood, 2002) and the 
motivation of a tourist is to learn something about the visited place (Dudek and Kowalczyk, 2003). In this case, the main objective of the tourist is to understand the cultural and natural history of the visited place (Epler Wood, 2002). We can also subsume activities that could link the environmental protection requirements with satisfying the specific needs of people in tourism, first of all in the experience from viewing wildlife. This group of touristic forms comprises wildlife viewing recreation (e.g. Higham and Bejder, 2008; Le Boeuf and Burney, 2013; Mustika et al., 2013), birdwatching (e.g. Collins-Kreiner et al., 2013) and whale-watching (e.g. Dimmock et al., 2014). The visitors' motives are the knowledge of nature and their stay in an intact and "original" landscape (Hvenegaard, 2002). Then the development of responsible tourism is based on education and the self-education of the visitors (Munro et al., 2008; Leung, 2012).
Then the outcome is an increase in their environmental awareness (Ballantyne et al., 2011), which could be manifested in changes in the behaviour of the tourists (Angelini et al., 2011; Hughes, 2013).

\section{Methodology}

The study area

The study area comprises a large-area of the protected territories in the Šumava Mountains and in the South Bohemia tourist regions (Figure 1) specified by the Czech Tourism Agency (Vagner and Perlin, 2010). This area covers the southern part of Bohemia near the border with Austria (Lower Austria, Upper Austria) and Germany (Bavaria).

The large-area and small-area protected natural territories in the selected tourist regions are above-average in their occupied area compared to the Czech Republic as a whole.

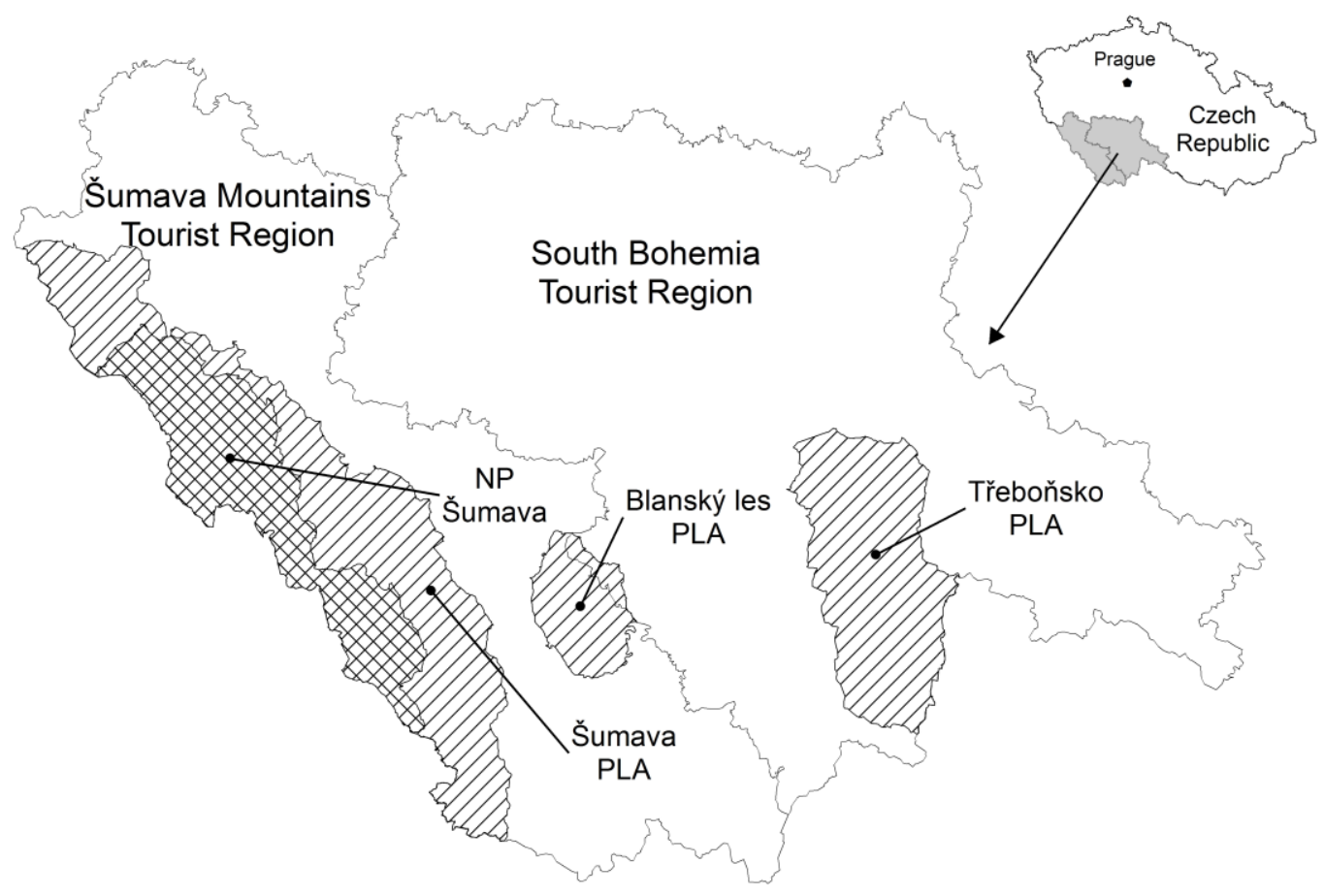

Figure 1. The Study area and Its Location within the Czech Republic.

Note: The Data sources are from the Czech Statistical Office and the Nature Conservation Agency of the Czech Republic 
The national parks and protected landscape areas cover more than one-fifth of this land. These protected areas play a huge role in the development of tourism in South Bohemia as well as in the Czech Republic (Vagner and Perlin, 2010). Certain interest groups in the area are aware of this situation, as proven by the fact that the conflict between the development of "mass" tourism and the nature protection has become a general political topic: the most important of its kind in the Czech Republic. As far as the touristic and protective importance of the Šumava Mountains Tourist Region goes, this organized nature protection is constantly under pressure from the efforts to disclose attractive natural sites (Novinky, 2010). It seems that these areas cannot currently withstand this pressure, which is supported by the development subtext of tourism. It will be necessary to take into account the growing masses of tourists and the increasing pressure of not only tourists but also of tourist infrastructure in the future (Novinky, 2011). Nevertheless, other areas are also in a similar situation (Havrlant, 2001; Havrlant, 2010; Foret and Klusacek, 2011). It has been shown that large-area protected territories represent a major concentration of accommodation facilities in the observed area and environment of the protected areas are the threatened ones, as intensively studied by Navrátil et al. (2013, 2014).

The Šumava PLA was established in 1975, and today it covers an area of $996 \mathrm{~km}^{2}$. The Šumava National Park, which is also a UNESCO Biosphere reserve, was not established until 1991, with an area of $680 \mathrm{~km}^{2}$. The mission of the area is to preserve and improve the existing natural environment, in particular to protect or restore the self-serving functions of the natural system, to strictly protect wild flora and fauna, and to preserve the typical appearance of the landscape. The area also serves to fulfil the scientific and educational goals, and moreover it is used for tourist and recreational activities that do not deteriorate the natural environment.

The Třeboňsko PLA was established in 1979 with an area of $700 \mathrm{~km}^{2}$. Even before this date, Třeboňsko had been declared as a Biosphere reserve in the UNESCO Man and the
Biosphere Programme in 1997. The purpose of this protected landscape area is to protect those landscapes, create a balanced environment, and to support the optimal development of agricultural, forestry, fishing, and mining activities in order to use those natural resources economically. The typical features of the local landscape include particularly the surface shaping given by its flat character, with numerous water features like watercourses, canals, ponds, and wetlands. The final appearance of the local landscape reflects the long-term harmonious coexistence of humans and nature.

The Blanský les PLA was established in 1979 with an area of $212 \mathrm{~km}^{2}$. Its purpose is to protect and gradually restore landscape values, its appearance, and its typical features. This natural area is very well preserved and it primarily serves to protect the surviving mixed forest vegetation, areas rich in flora and located on the serpentine and limestone subsoil, and to protect the characteristic landscape appearance. Forest communities are preserved in relatively large areas and the species composition and structure are close to the presumed original state of that vegetation.

\section{Data collection}

The data was collected in the field by means of structured interviews with tourists (as defined by UNWTO), whose responses were filled into the prepared forms. This survey took place during the 2013 summer tourist season (from June to September, inclusive) and it was carried out by trained students in the abovementioned large-area protected natural territories. The pilot research was carried out on a sample of thirty respondents in May 2013.

Considering the fact that obtaining a totally random selection is practically impossible, an arbitrary selection of the respondents was supported by specific rules set for the selection. This research was carried out during both workdays and weekends (Petrick et al., 2001). Under the circumstances of a low daily volume of visitors, every visitor was approached (Farber and Hall, 2007), while in the case of a medium visit volume, every fifth visitor was approached, and in the case of a high visit volume, every tenth visitor was approached. 
The protected areas: are they still in the 'pleasure periphery' or are they destinations for sustainable tourism activities?

The aim was to obtain 500 completed questionnaires from each protected area (Table 1).

Table 1. Sample characteristics, $n=1500$.

\begin{tabular}{lr}
\hline Gender & \\
\hline Female & $51.4 \%$ \\
Male & $48.6 \%$ \\
\hline Age groups & \\
\hline $18-25$ years & $17.5 \%$ \\
$26-35$ years & $19.7 \%$ \\
$36-45$ years & $18.3 \%$ \\
$46-55$ years & $16.7 \%$ \\
$56-65$ years & $13.1 \%$ \\
$66-75$ years & $10.5 \%$ \\
over 75 years & $4.1 \%$ \\
\hline
\end{tabular}

The tool for measuring the degree of participation in respective recreation activities of these tourists involved: hiking; bicycle tourism; recreational sport activities (swimming, tennis, etc.); wellness activities and spa procedures; nature observation; visits to historical sights (castles, chateaux); visits to museums, galleries, historical sights, etc.; games with children; relaxation; entertainment; and shopping. The degree of participation was measured on a five-point scale from 1 ("I do not participate in the activity") to 5 ("I mostly participate in this activity"). The questionnaire was supplemented by questions on age and gender (Table 1).

\section{Data analysis}

The information about the degree of participation in recreational activities was initially and separately processed for each activity. The relative importance of these individual activities was assessed by using a one-way analysis of variance and Tukey's HSD Post-hoc Test for the unequal number of $n$. The test of mutually non-differing groups was carried out at the level of $p>0.01$. Given that there was a massive research into the area of recreational activities of tourists using the same query tool in previous years from 2009-2011 (Navratil et al., 2013), it was possible to test the differences in the average values for the degree of participation in the activities between the visitors to the protected areas and the visitors to the entire area. A two-sample t-test was used for this purpose (Quinn and Keough, 2002).

The typology of the recreational activities of the tourists was performed using the cluster analysis. First the linkage between the respective activities was assessed using the complete Linkage Hierarchical Cluster Analysis with the Squared Euclidean Distance. The multivariate proximity of the participation in the activities was assessed based on the dendrogram.

The same procedure was applied in the clustering of the individual cases (i.e., the respondents) and the "optimal" number of clusters was assessed for further analysis. Then this number was set in identifying groups of respondents using the K-means clustering. The one-way analysis of variance and the Tukey's HSD Post-hoc Test for the unequal number of $n$ were again used to identify the content of each group. The test of mutually non-differing groups was carried out at the level of $p>0.01$.

\section{Results and discussion}

The degree of participation in recreational activities among tourists in the protected areas substantially differs (ANOVA: $F(10 ; 16,500)=$ 284.38; $p<0.001$ ). "Relaxation" is listed as the most prominent activity (Figure 2). The largearea protected territories are thus perceived primarily as destinations for relaxation (Eagles and McCool, 2002). The reason is obvious: such large areas are optimal places for relaxation away from city life. The main recreational strength for relaxation lies in the pleasant "natural" environment (Navratil et al., 2011). The large-area protected territories thus represent something usually called "naturebased tourism" (Lund, 2013; Pröbstl and Haider, 2013). In other words, it represents tourism that is conditioned by the existence of a natural environment that is, in today's world, primarily bound to protected natural areas. From the global point of view, it mainly concerns places of "wilderness" (Hall and Page, 2006), protected as national parks (Whitelaw et al., 2014). However, it is the mass of visitors to such places that causes the greatest loss of natural values and leads to the 
biggest conflicts between environmental protection and tourism activities (Monz et al., 2010; Pickering, 2010; Pickering et al., 2010; Barros et al., 2013). The protected areas have to take into account consistent high pressure on their "natural" environment (Balmford et al., 2009).

This pressure is confirmed by "entertainment" in second place in the ranking of participation in activities. We know that entertainment is one of the main driving forces behind the development of various types of destinations (Ritchie and Crouch, 2003). It plays an important part in attracting visitors to environmentally significant areas (Ballantyne et al., 2011), and yet entertainment features are among the main causes of conflicts between tourism and environmental protection (Cater, 1995; Neto, 2003). On the other hand, the use of entertainment features has a high potential for education for visitors who are learning something from their visit to precious "natural" sites (Cecioni, 2005; Ferreira, 1998).

The average values for "exploring nature" correspond to the values of entertainment; the average values for the degree of participation also do not differ from the ones for other recreational activities supported by a pleasant "natural" environment in recreational sports activities such as swimming, tennis, etc. (Figure 2). The above average values were reached by activities such as hiking and visits to historical sights and attractions (castles, chateaux). On the contrary, wellness activities,

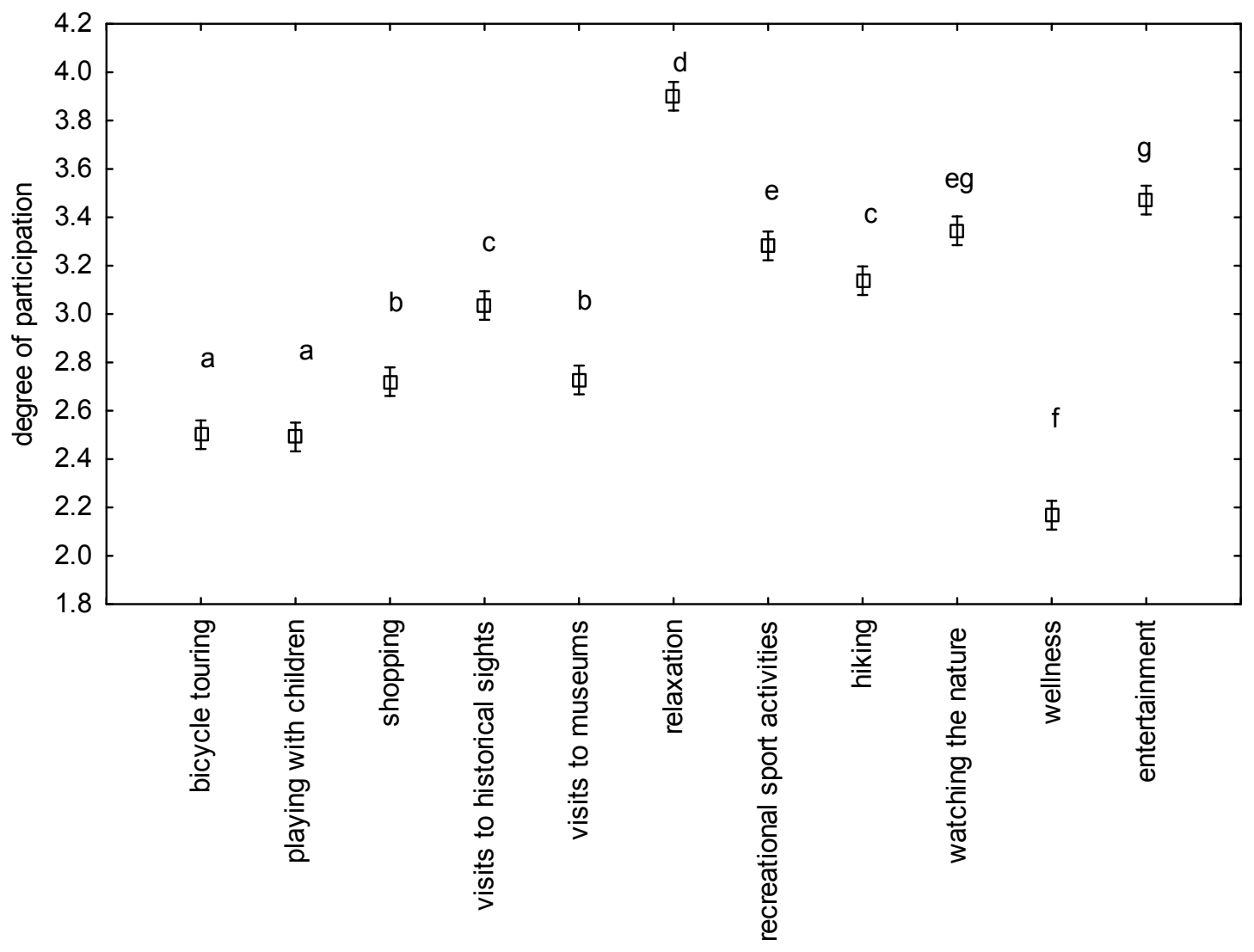

Figure 2. Degree of participation in the activity among the visitors to the large-area protected territories

Note: The average values and 0.95 confidence intervals have been showed. Those averages marked with the same letter do not significantly differ (the Tukey's HSD Post-hoc Test for unequal sample sizes, $p>0.01$ ), $n=1,500$. 
bicycle touring, and playing with children reached the lowest average values.

In order to be able to assess the importance of the protected areas in activities performed by tourists to the larger investigated area as a whole, it is necessary to compare the result values to previous research in the area. The results are summarized in Table 2 . The overall scheme of the tourists' participation in activities in the investigated regions and the protected areas is analogical. Nevertheless, there was a statistically prominent difference in all activities of each performed activity. There are more activities performed for which a pleasant natural environment is an important prerequisite in the large-area protected territories. The largest shift was observed in the case of the wellness activities and the entertainment, followed by relaxation activities and sports (Table 2). This comparison confirms the results of a separate analysis of the visitors' activities in the protected areas. Generally it concerns those visitors who are oriented towards leisure and recreational activities for which the protected areas are an optimal environment and not a subject of interest and knowledge per se (Karanth and DeFries, 2011).

The results of each activity suggest that a view of the overall structure of the performed activities should be interesting as well. Two types of jointly performed activities were mainly defined using the Complete Linkage Hierarchical Cluster Analysis, (Figure 3). The first one is tourism involving entertainment, relaxation and recreational physical activities (merged with a level of information loss of about $45 \%$ ). The second type is sightseeing tourism. Individual activities are merged there with a level of information loss of less than $40 \%$. Then it splits into nature-based sightseeing (with a level of information loss of about $25 \%$ ) and cultural/historical sightseeing (with a level of information loss of about 20\%). Other activities were not significantly merged

Table 2. The comparison of the degree of visitors' participation in individual activities in large-area protected territories and the total number of visitors in the investigated area.

\begin{tabular}{|c|c|c|c|c|}
\hline Activity & Sample & Mean & Variance & t-test \\
\hline \multirow{2}{*}{ Wellness } & Tourism regions & 1.848 & 1.454 & \multirow{2}{*}{-8.661} \\
\hline & Protected areas & 2.168 & 1.473 & \\
\hline \multirow{2}{*}{ Historical sights } & Tourism regions & 3.322 & 1.592 & \multirow{2}{*}{8.388} \\
\hline & Protected areas & 3.035 & 1.121 & \\
\hline \multirow{2}{*}{ Museums } & Tourism regions & 2.852 & 1.724 & \multirow{2}{*}{3.581} \\
\hline & Protected areas & 2.728 & 1.120 & \\
\hline \multirow{2}{*}{ Shopping } & Tourism regions & 2.541 & 1.621 & \multirow{2}{*}{-4.732} \\
\hline & Protected areas & 2.720 & 1.507 & \\
\hline \multirow{2}{*}{ Entertainment } & Tourism regions & 2.964 & 1.790 & \multirow{2}{*}{-13.805} \\
\hline & Protected areas & 3.471 & 1.313 & \\
\hline \multirow{2}{*}{ Relaxation } & Tourism regions & 3.739 & 1.445 & \multirow{2}{*}{-4.871} \\
\hline & Protected areas & 3.901 & 1.077 & \\
\hline \multirow{2}{*}{ Nature observation } & Tourism regions & 3.706 & 1.447 & \multirow{2}{*}{10.703} \\
\hline & Protected areas & 3.344 & 1.141 & \\
\hline \multirow{2}{*}{ Bicycle tourism } & Tourism regions & 2.697 & 2.408 & \multirow{2}{*}{4.694} \\
\hline & Protected areas & 2.501 & 1.661 & \\
\hline \multirow{2}{*}{ Sport activities } & Tourism regions & 3.053 & 1.888 & \multirow{2}{*}{-5.872} \\
\hline & Protected areas & 3.282 & 1.535 & \\
\hline \multirow{2}{*}{ Hiking } & Tourism regions & 3.328 & 1.754 & \multirow{2}{*}{5.117} \\
\hline & Protected areas & 3.138 & 1.383 & \\
\hline
\end{tabular}

Note: The data for the whole area are taken from Navratil et al., 2013; two-tailed pair t-test was used, all values are significant at $p<0.001, n=1500$. 
Navrátil J., J. Knotek, K. Pícha and J. Fialová (2015) / European Journal of Tourism Research 11, pp. 57-72

together, and they have been assigned to other types of activities by using statistical methods; (However, it was done at a level of information loss of $60 \%$ and more). The definition of these two broad types is logical and fully corresponds to the basic motivational elements influencing the visits to such places (Cheung and Fok, 2014; Yoon and Uysal, 2005).

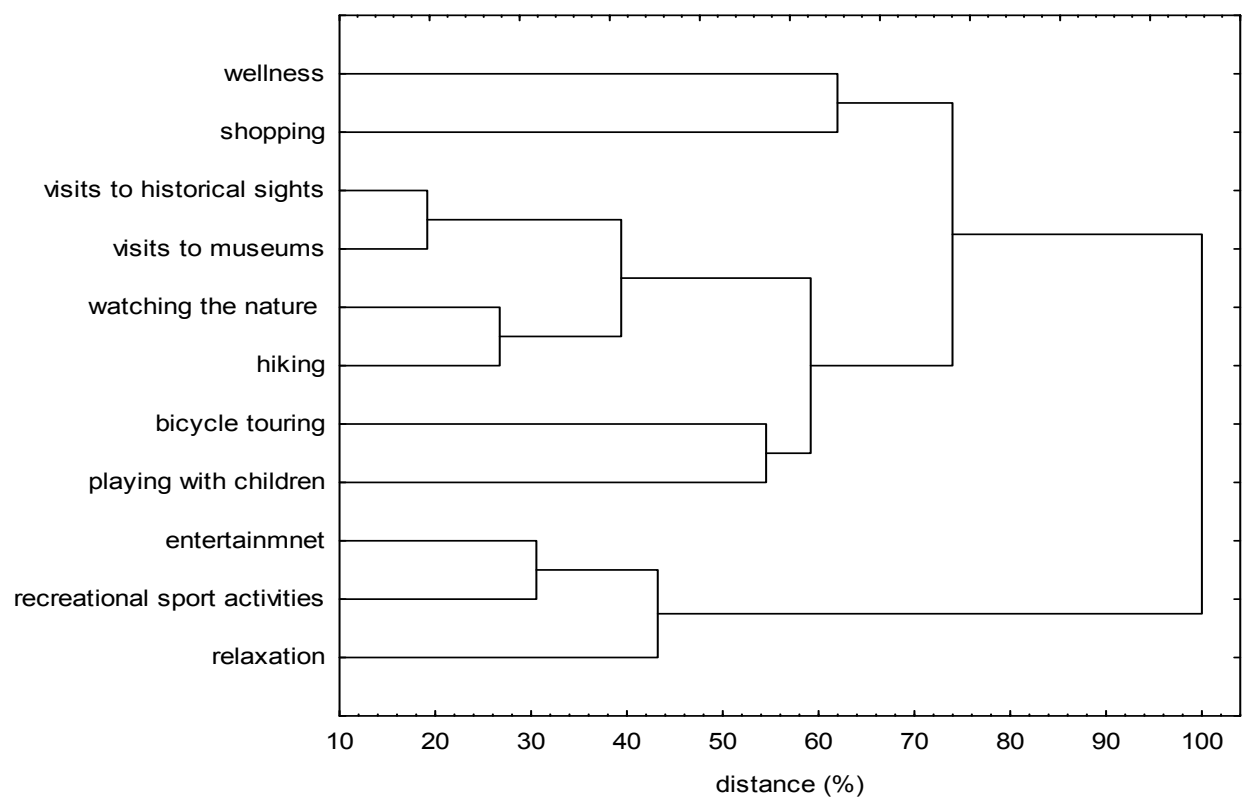

Figure 3. The dendrogram of a joint assessment of recreation activities.

Note: The figure shows the results of the Complete Linkage Hierarchical Cluster Analysis, $n=1500$.

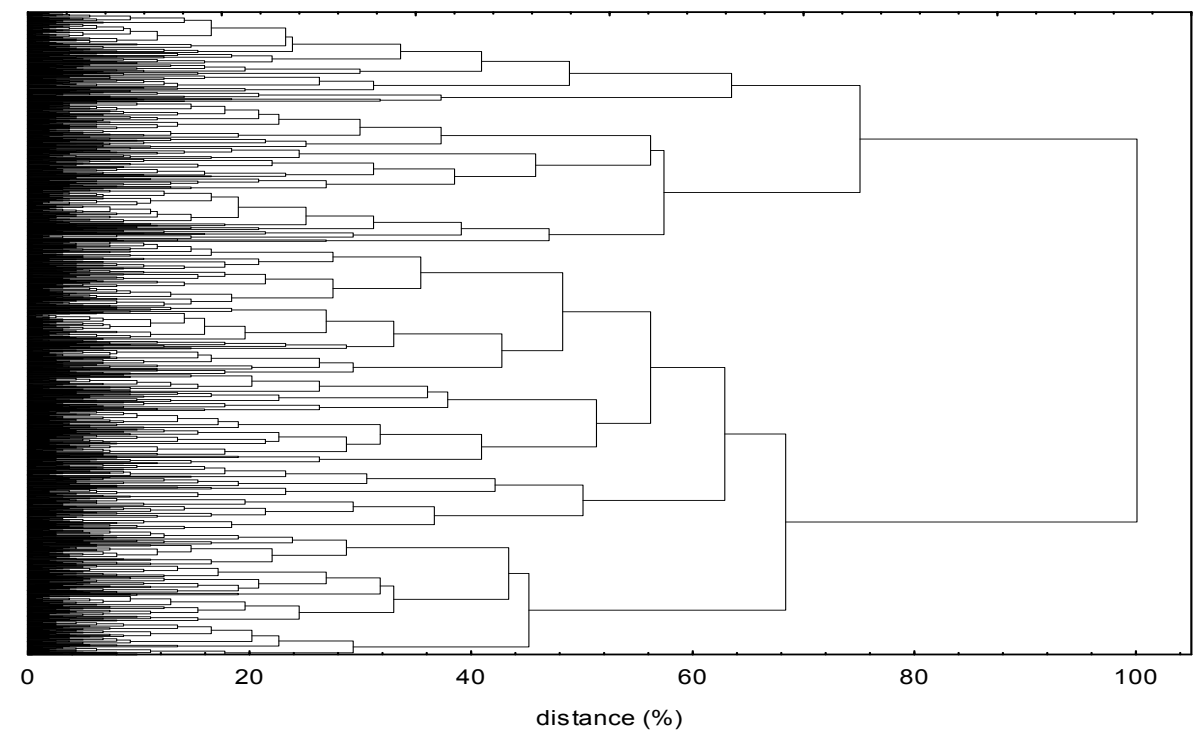

Figure 4. Classification of the respondents

Note: The classification is based on a joint assessment of the recreational activities and the classification of the respondents. This shows the results of the Complete Linkage Hierarchical Cluster Analysis, n = 1500 . 
Subsequently, the degree of participation in recreational activities on a holiday was used for the purpose of a basic segmentation of the visitors according to their prevailing behaviour. The number of groups determined by the dendrogram was four (Figure 4). It can be seen that there are two main groups, which are further split into multiple smaller groups. These groups are quite close to the group of stakeholders that were identified by Brown et al. (2015) as well as the motivational factors identified by Kibicho (2006).

As for the level of creating a group is concerned, the level of information loss was set to $65 \%$, which is a greater information loss than usual (Real, Arce and Sabucedo, 2000). The respondents were assigned to groups according to K-means Clustering. The resulting groups are meaningful and characterize the structure of the respondents well (see below).

Based on the different average values of participation in each activity (Table 3 ), four groups were identified: (1) the passive visitors, (2) the visitors focused on exploring but not participating in any physical activity, (3) the active visitors with a dominant interest in bicycle touring, and (4) the active visitors with a dominant interest in history. The first group, comprising more than a fifth of all visitors
$(21.79 \%)$, involves the passive visitors whose only significant activity (with the average above 3 ) is relaxation. Four of the activities do not even reach the average of two. Overall, with the exception of relaxation, all the other activities reach the minimum average values for participation in the activities. In the overall number of visits, this segment corresponds (Navratil et al., 2013) to the passive and nonengaged tourism segment (Lanfranchi at al., 2014), except for the fact that the average values of interest in the activities are generally lower in the case of protected areas. The second of the identified segments also has its influence on the overall visits to the region: this type is known as hotel-based tourism (Weaver, 2006; Ahmad, 2014), which is characteristic in its low values for physical activities and high values for mainly history but also for entertainment and especially shopping (maximum of the defined segments). It involves the smallest number of the respondents $(13.79 \%)$.

The other two segments differ from the aforementioned ones mostly due to their high values for physical activities such as hiking, bicycle touring, and recreational sport activities. The absolute number of activities has above average values for the participation of both groups. Though they differ significantly only in

Table 3. Degree of participation in recreational activities for the segments of demand

\begin{tabular}{|c|c|c|c|c|c|c|c|c|c|c|c|}
\hline \multirow[b]{3}{*}{ Wellness } & \multicolumn{2}{|c|}{ Passive } & \multicolumn{3}{|c|}{$\begin{array}{c}\text { Exploring without any } \\
\text { physical activity }\end{array}$} & \multicolumn{3}{|c|}{$\begin{array}{c}\text { Active with a } \\
\text { dominant interest in } \\
\text { bicycle touring }\end{array}$} & \multicolumn{3}{|c|}{$\begin{array}{c}\text { Active with a } \\
\text { dominant interest } \\
\text { in history }\end{array}$} \\
\hline & average & \multirow{2}{*}{$\frac{\text { SEM }}{0.07}$} & \multicolumn{2}{|c|}{ average } & \multirow{2}{*}{$\frac{\text { SEM }}{0.08}$} & \multicolumn{2}{|c|}{ average } & \multirow{2}{*}{$\frac{\text { SEM }}{0.07}$} & \multicolumn{2}{|c|}{ average } & \multirow{2}{*}{$\frac{\text { SEM }}{0.05}$} \\
\hline & $1.92 \mathrm{a}$ & & 2.19 & $a b$ & & 2.16 & $a b$ & & 2.28 & $\mathrm{~b}$ & \\
\hline Visits to historical sights & $2.30 \mathrm{~b}$ & 0.05 & 3.05 & a & 0.06 & 2.79 & $d$ & 0.05 & 3.50 & c & 0.04 \\
\hline Visits to museums & $1.88 \mathrm{~b}$ & 0.04 & 2.79 & a & 0.07 & 2.52 & $d$ & 0.05 & 3.21 & c & 0.04 \\
\hline Shopping & $2.43 \mathrm{~b}$ & 0.06 & 3.21 & a & 0.08 & 2.55 & bc & 0.06 & 2.78 & c & 0.05 \\
\hline Entertainment & 2.95 a & 0.07 & 3.10 & a & 0.08 & 3.79 & $b$ & 0.05 & 3.70 & $b$ & 0.04 \\
\hline Relaxation & 3.49 a & 0.07 & 3.47 & a & 0.07 & 4.10 & $b$ & 0.05 & 4.14 & $b$ & 0.04 \\
\hline Nature observation & $2.57 \mathrm{~b}$ & 0.06 & 3.17 & a & 0.06 & 3.61 & c & 0.06 & 3.66 & c & 0.04 \\
\hline Bicycle tourism & $1.66 \mathrm{~b}$ & 0.05 & 1.99 & a & 0.07 & 3.56 & d & 0.05 & 2.60 & c & 0.05 \\
\hline Recreational sport activities & 2.39 a & 0.07 & 2.55 & a & 0.07 & 3.86 & $b$ & 0.05 & 3.68 & $b$ & 0.04 \\
\hline Hiking & $2.14 \mathrm{~b}$ & 0.06 & 2.67 & a & 0.07 & 3.58 & c & 0.06 & 3.57 & c & 0.04 \\
\hline Games with children & $1.89 \mathrm{~b}$ & 0.06 & 2.41 & a & 0.09 & 2.84 & $\mathrm{c}$ & 0.08 & 2.66 & $\mathrm{ac}$ & 0.05 \\
\hline
\end{tabular}

Note: The average values and mean error (SEM) are shown. Those averages marked with the same letter do not significantly differ (Tukey's HSD Post hoc Test for unequal sample sizes, $p>0.01$ ), $n=1,500$. 
a small number of activities, this difference is substantial. While the first one shows an incomparably higher interest in bicycle touring in comparison with the other segments, the second group shows a greater interest in history. Thus the first group corresponds to the segment which is marked in the analysis as "modern outdoor tourism", and the second group corresponds to "traditional outdoor tourism" (Weber and Anderson, 2010). The active visitors with a dominant interest in bicycle touring represent a fifth of the visits (19.59\%), while active visitors with a dominant interest in history represent nearly a half of all of the visits $(44.84 \%)$. Bicycle tourism in particular seems to be an important differentiating factor in the overall visits because people interested in this activity have different beliefs than "other" tourists (Ramthun and Armistead, 2000).

\section{Conclusion}

The most prominent activity among tourists in large-area protected natural territories is relaxation. Thus, large-area protected territories are perceived primarily as destinations for relaxation. Entertainment is the second most important activity. As to the third and the fourth places are concerned (that are occupied by recreational sport activities like swimming, tennis, etc.), we can speak of largearea protected natural territories as being destinations for "nature-based tourism", which is conditioned by the existence of the natural environment, which is primarily bound to the protected natural areas, and not for ecotourism. According to the levels of participation in recreational activities, there were four segments of demand that were identified in the visits to the large-area protected natural territories: (1) passive visitors, (2) visitors focused on exploring but not participating in any physical activity, (3) active visitors with a dominant interest in bicycle touring, and (4) active visitors with a dominant interest in history.

The protected areas keep representing an "escape location" for an important group of tourists, i.e., a pleasure periphery that is near enough to get to and far enough away so that it could be sufficiently special to relax in. The surveyed tourists were not found to be primarily oriented towards eco-tourism; they are not ecoconscious, but they are looking for an environment full of nature. The managers of these protected areas, (in collaboration with other groups of stakeholders) should consider the potential of the particular parts of the protected areas in order to undertake tourist activities sustainably so that there is an offer for those particular identified segments as mentioned above.

This article has studied the structure of tourists in the particular protected areas in more detail. This fact limits the possibility to generalize the revealed facts for other protected areas to some degree. Further research could give attention to the impact of every kind of particular tourist activities in the natural environment of the protected area, when it comes to define an acceptable degree of undertaking those activities in the sense of sustainability.

\section{Acknowledgement}

The field survey and the preparation of this paper were supported by the Czech Science Foundation - GACR P404/12/0334 'Factors of visitors' in relation to the ambience of attractions in vulnerable areas.'

\section{References}

Ahmad, R. (2014). Habitus, capital, and patterns of taste in tourism consumption: A study of western tourism consumers in India. Journal of Hospitality and Tourism Research, 38(4), 487-505

Angelini, R., Ferreira, J. S., do Carmo Araujo, C. S., \& Carvalho, A. R. (2011). Effect of outdoor and laboratorial environment science activities on middle school students understanding on conservation. Natureza \& Conservacao, 9(1), 93-97

Ballantyne, R., Packer, J., \& Falk, J. (2011). Visitors' learning for environmental sustainability: Testing short- and longterm impacts of wildlife tourism experiences using structural equation modelling. Tourism Management, 32(6), 1243-1252.

Balmford, A., Beresford, J., Green, J., Naidoo, R., Walpole, M., \& Manica, A. (2009). A 
global perspective on trends in naturebased tourism. Plos Biology, 7(6), e1000144.

Barros, A., Gonnet, J., Pickering, C. (2013) Impacts of informal trails on vegetation and soils in the highest protected area in the Southern Hemisphere. Journal of Environmental Management, 127, 5060.

Bernat, S. (2014) Soundscapes and tourism Towards sustainable tourism. Problemy Ekorozwoju, 9(1), 107-117.

Borges, M., C. Eusébio, Carvalho N. (2014) Governance for sustainable tourism: A review and directions for future research. European Journal of Tourism Research, 7, 45-56.

Brown, G., de Bie, K., \& \& Weber, D. (2015). Identifying public land stakeholder perspectives for implementing placebased land management. Landscape and Urban Planning, 139, 1-15.

Bushell, R., \& McCool, S. F. (2007). Tourism as a tool for conservation and support of protected areas: Setting the agenda. In R. Bushell, P. F. J. Eagles (Eds.) (2007) Tourism and protected areas: Benefits beyond boundaries, The Vth IUCN World Parks Congress. Wallingford: CABI, 12-26.

Bushell, R., Staiff, R., \& Eagles, P. F. J. (2007) Tourism and protected areas: Benefits beyond boundaries. In R. Bushell, P. F. J. Eagles (Eds.) (2007) Tourism and protected areas: Benefits beyond boundaries, The Vth IUCN World Parks Congress. Wallingford: CABI, 1-11.

Cater, E. (1995). Environmental contradictions in sustainable tourism. Geographical Journal, 161(1), 21-28.

Cecioni, E. (2005). Environmental education and geography of complexity. International Research in Geographical and Environmental Education, 14(4), 277-294.

Cetkovsky, S., Klusacek, P., Martinat, S., \& Zapletalova, J. (2007). Some aspects of cross-border cooperation in Euroregions of the Czech Republic: An example of the Šumava Region. Moravian Geographical Reports, 15(1), 43-55.
Cheung, L. T. O., \& Fok, L. (2014). The motivations and environmental attitudes of nature-based visitors to protected areas in Hong Kong. International Journal of Sustainable Development and World Ecology, 21(1), 28-38.

Collins-Kreiner, N., Malkinson, D., Labinger, Z., \& Shtainvarz, R. (2013). Are birders good for birds? Bird conservation through tourism management in the Hula Valley, Israel. Tourism Management, 38, 31-42.

Dimmock, K., Hawkins, E. R., \& Tiyce, M. (2014). Stakeholders, industry knowledge and adaptive management in the Australian whale-watching industry. Journal of Sustainable Tourism, 22(7), 1108-1121.

Dudek, A., \& Kowalczyk, A. (2003). Turystyka na obszarach chronionych: Szanse i zagrożenia. Prace $i$ Studia Geograficzne 32, 117-140.

Eagles, P. F., \& McCool, S. F. (2002). Tourism in national parks and protected areas: Planning and management. CABI.

Epler Wood, M. (2002). Ecotourism: Principles, practices and policies for sustainability. Nairobi: UNEP.

Farber, M. E., \& Hall, T. E. (2007). Emotion and environment: Visitors' extraordinary experiences along the Dalton Highway in Alaska. Journal of Leisure Research, 39(2), 248-270

Ferreira, G. (1998). Environmental education through hiking: A qualitative investigation. Environmental Education Research, 4(2), 177-183.

Foret, M., \& Klusacek, P. (2011). The importance of the partnership and cooperation in the regional development exampled on Znojmo region. Acta Universitatis Agriculturae et Silviculturae Mendelianae Brunensis, 59(4), 79-86

Frantal, B., \& Urbankova, R. (2014). Energy tourism: An emerging field of study. Current Issues in Tourism. doi: 10.1080/13683500.2014.987734

Fredman, P., \& Sandell, K. (2009) 'Protect, preserve, present' The role of tourism in Swedish national parks. In W. Frost, C. M. Hall (Eds.) (2009) Tourism and 
Navrátil J., J. Knotek, K. Pícha and J. Fialová (2015) / European Journal of Tourism Research 11, pp. 57-72

national parks. International perspectives on development, histories and change. London: Routledge, 197207.

Frost, W., Hall, C. M. (2009). Reinterpreting the creation myth. In W. Frost, C. M. Hall (Eds.) (2009) Tourism and national parks: International perspectives on development, histories and change. London: Routledge, 16-29.

Geneletti, D., \& Dawa, D. (2009) Environmental impact assessment of mountain tourism in developing regions: A study in Ladakh, Indian Himalaya. Environmental Impact Assessment Review, 29(4), 229-242.

Hall, C. M., \& Frost, W. (2009a). Introduction: The making of the national parks concept. In W. Frost, C. M. Hall (Eds.) (2009) Tourism and national parks: International perspectives on development, histories and change. London: Routledge, 3-15.

Hall, C. M., \& Frost, W. (2009b). National parks ant the 'worthless lands hypothesis' revisited. In W. Frost, C. M. Hall (Eds.) (2009) Tourism and national parks: International perspectives on development, histories and change. London: Routledge, 46-62.

Hall, C. M., \& Lew, A. A. (2009). Understanding and managing tourism impacts: An integrated approach. London: Routledge.

Hall, C. M., \& Page, S. (2006). The geography of tourism and recreation: Environment, place and space. London: Routledge.

Havrlant, J. (2001). The Beskydy Mountains specific features and problems of the tourist area. Geografski Obzornik, 48(4), 23-26.

Havrlant, J. (2010). The recreational potential of the Jeseníky Region (Czech Republic and the influence of soft factors on its devellopment). Moravian Geographical Reports 18(1), 23-37.

Higham, J. E. S., \& Bejder, L. (2008). Managing wildlife-based tourism: Edging slowly towards sustainability? Current Issues in Tourism, 11(1), 7583.

Holden, A. (2000). Environment and tourism. London; New York: Routledge.
Hughes, K. (2013). Measuring the impact of viewing wildlife: Do positive intentions equate to long-term changes in conservation behaviour? Journal of Sustainable Tourism, 21(1), 42-59.

Hvenegaard, G. T. (2002). Using tourist typologies for ecotourism research. Journal of Ecotourism 1(1), 7-18.

IUCN (2014). IUCN Protected areas categories system.

URL:

http://www.iucn.org/about/work/progra mmes/gpap_home/gpap_quality/gpap_ pacategories/ (Accessed on 14.5.2014).

Jamal, T. B., Stein, S. M., \& Harper, T. L. (2002). Beyond labels - Pragmatic planning in multistakeholder tourismenvironmental conflicts. Journal of Planning Education and Research, 22(2), 165-177.

Karanth, K. K., DeFries, R. (2011). Naturebased tourism in Indian protected areas: New challenges for park management. Conservation Letters, 4(2), 137-149.

Kayat, K. (2008). Stakeholders' perspectives toward a community-based rural tourism development. European Journal of Tourism Research, 1(2), 94111.

Kibicho, W. (2006). Tourists to Amboseli National Park: A factor-cluster segmentation analysis. Journal of Vacation Marketing, 12(3), 218-231.

Kline, J. D. (2001). Tourism and natural resource management: a general overview of research and issues. Gen. Tech. Rep. PNW-GTR-506, Portland.

Kroupova, S., Navratil, J., Picha, K., \& Hasman, M. (2014). Differentiation of the demand for the hunting tourism in the Czech Republic. Czech Journal of Tourism 3(1), 27-42.

Lanfranchi, M., Giannetto, C., \& De Pascale, A. (2014). Nature based tourism: Natural balance, impacts and management. Quality - Access to Success, 15 (SUPPL.1), 224-229.

Le Boeuf, B. J., \& Campagna, C. (2013). Wildlife viewing spectacles: Best practices from Elephant seal (Mirounga sp.) colonies. Aquatic Mammals 39(2), 132-146. 
Lee, T. H., Jan, F. H., \& Yang, C. C. (2013). Conceptualizing and measuring environmentally responsible behaviors from the perspective of communitybased tourists. Tourism Management, $36,454-468$.

Leslie, D. (2012). Introduction. In D. Leslie (Ed.) (2012). Responsible tourism: Concepts, theory and practice. Wallingford: $C A B I, 1-16$

Leung, Y.-F. (2012). Recreation ecology research in East Asia's protected areas: Redefining impacts? Journal for Nature Conservation, 20(6), 349-356.

Lourens, M. (2007). Route tourism: a roadmap for successful destinations and local economic development. Development Southern Africa, 24(3), 475-489.

Lund, K. A. (2013). Experiencing nature in nature-based tourism. Tourist Studies, 13(2), 156-171.

Marion, J. L., \& Leung, Y. (2001). Trail resource impact and an examination of alternative assessment techniques. Journal of Park and Recreation Administration, 19(3), 17-37.

Marion, J. L., \& Reid, S. E. (2007). Minimising visitor impacts to protected areas: The efficacy of low impact education programmes. Journal of Sustainable Tourism, 15(1), 5-27.

Mark, S. R. (2009). Framing the view: How American national parks become to be. In W. Frost, C. M. Hall (Eds.) (2009) Tourism and national parks: International perspectives on development, histories and change. London: Routledge, 81-87.

McClanahan, T. R, Cinner, J., Kamukuru, A. T., Abunge, C., \& Ndagala, J. (2008). Management preferences, perceived benefits and conflicts among resource users and managers in the Mafia Island Marine Park, Tanzania. Enviromental Conservation, 35(4), 340-350.

Monz, C. A., Marion, J. L., Goonan, K. A., Manning, R. E., Wimpey, J., \& Carr, C. (2010) Assessment and monitoring of recreation impacts and resource conditions on mountain summits: Examples from the Northern Forest, USA. Mountain Research and Development, 30(4), 332-343.
Munro, J. K., Morrison-Saunders, A., \& Hughes, M. (2008). Environmental interpretation evaluation in natural areas. Journal of Ecotourism, 7(1), 114.

Mustika, P. L. K., Birtles, A., Everingham, Y., \& Marsh, H. (2013). The human dimensions of wildlife tourism in a developing country: watching spinner dolphins at Lovina, Bali, Indonesia. Journal of Sustainable Tourism, 21(2), 229-251.

Navrátil, J., Lesjak, M., Pícha, K., Martinát, S., Navrátilová, J., White Baravalle Gilliam, V. L., \& Rajchard, J. (2014). The importance of vulnerable areas with potential tourism development: A case study of the Bohemian Forest and South Bohemia tourism regions. Acta Geographica Slovenica, 54(1), 115130.

Navratil, J., Picha, K., Martinat, S., Knotek, J., Kucera, T., Balounova, Z., \& Rajchard, J. (2013). A model for the identification of areas favourable for the development of tourism: A case study of the Sumava Mts. and South Bohemia Tourist regions (Czech Republic). Moravian Geographical Reports, 21(1), 25-40.

Navratil, J., Picha, K., Rajchard, J., \& Navratilova, J. (2011). Impact of visit on visitors' perceptions of the environments of nature-based tourism sites. Tourism 59(1), 7-23.

Neto, F. (2003). A new approach to sustainable tourism development: Moving beyond environmental protection. Natural Resources Forum 27(3), 212-222.

Neasome, D., Moore, S. A., \& Dowling, R. K. (2013). Natural area tourism. Ecology, impacts and management. Bristol: Channel View Publications.

Nicholls, S., \& Kang, S. (2012). Going green: the adoption of environmental initiatives in Michigan's lodging sector. Journal of Sustainable Tourism 20(7), 953-974.

Novinky (2010). Šumava se má opět otevřít turistum, rozhodl soud. URL: http://www.novinky.cz/domaci/219798sumava-se-ma-opet-otevrit-turistumrozhodl-soud.html (Accessed on 5.12.2011) 
Navrátil J., J. Knotek, K. Pícha and J. Fialová (2015) / European Journal of Tourism Research 11, pp. 57-72

Novinky (2011). První zónu parku Šumava protne lanovka, schválili jihočeští radní. URL:

http://www.novinky.cz/domaci/243339prvni-zonu-parku-sumava-protnelanovka-schvalili-jihocesti-radni.html (Accessed on 5.12.2011)

Ogonowska, M., \& D. Torre (2013). Sustainable tourism and the emergence of new environmental norms. European Journal of Tourism Research 6(2), 141153.

Olwig, K., \& Olwig, K. (1979). Underdevelopment and the development of "natural“ parks ideology. Antipode 11(2), 16-25.

Petrick, J. F., Morais, D. D., \& Norman, W. C. (2001). An examination of the determinants of entertainment vacationers' intentions to revisit. Journal of Travel Research 40(1), 4148.

Pickering, C. M. (2010). Ten factors that affect the severity of environmental impacts of visitors in protected areas. Ambio 39(1), 70-77.

Pickering, C. M., Hill, W., Newsome, D., \& Leung, Y. F. (2010). Comparing hiking, mountain biking and horse riding impacts on vegetation and soils in Australia and the United States of America. Journal of Environmental Management, 91(3), 551-562.

Pröbstl, U., \& Haider, W. (2013). Challenges for outdoor recreation and nature based tourism. Journal of Outdoor Recreation and Tourism, 1-2, iii-iv

Quinn, G. P., \& Keough, M. J. (2002). Experimental design and data analysis for biologists. Cambridge: Cambridge University Press.

Ramthun, R., \& Armistead, J. D. (2000). A measurement of the experience preferences of Central Appalachian mountain bicyclists. Proceedings of the 2000 Northeastern Recreation Research Symposium 276, 104-106

Real, E., Arce, C., \& Sabucedo, J. M. (2000). Classification of landscapes using quantitative and categorical data, and prediction of their scenic beauty in north-western Spain. Journal of Environmental Psychology 20(4), 355373.
Ritchie, J. R. B., \& Crouch, G. I. (2003) The competitive destination: a sustainable tourism perspective. Wallingford: CABI Publishing.

Santana-Jiménez, Y., Hernández, J. M., \& Suárez-Vega, R. (2013). Estimating the environmental attractions of rural tourism lodging units in La Gomera island, Spain. European Journal of Tourism Research, 6(2), 132-140.

Sjøholt, P. (2000). Eco-tourism and local development. Conceptual and theoretical framework and problems in implementation. Empirical evidence from Costa Rica and Ecuador. Fennia, 178(2), 227-241.

Spenceley, A. (2008). Introduction: Responsible tourism in Southern Africa. In A. Spenceley (Ed.) (2008) Responsible tourism: Critical issues for conservation and development. London: Earthscan, 1-26.

Svec, R., Navratil, J., Picha, K., \& White Baravalle Gilliam, V. L. (2012). The perception of the quality of accommodation establishments' product. DETUROPE: Central European Journal of Regional Development and Tourism 4(2), 4-21.

Tomljenović, R., \& I. Kunst (2014). From sun and sea tourism to cultural tourism the case of Split-Dalmatia county. European Journal of Tourism Research 8, 83-98.

Vagner, J., \& Perlin, R. (2010). Turistické regiony České republiky. CzechTourism a ministerstvo pro místní rozvoj České republiky. Informace České geografické společnosti 30(1), 38-41.

Vasiljević, D. A., Marković, S. B., Hose, T. A., Smalley, I., O'Hara-Dhand, K., Basarin, B., Lukić, T., \& Vujičić, M. D. (2011). Loess towards (geo) tourism proposed application on loess in Vojvodina region (north Serbia). Acta Geographica Slovenica, 51(2), 390406.

Weaver, D. (2006). Sustainable tourism: Theory and practice. London, New York: Routledge.

Weiler, B., \& Davis, D. (1993). An exploratory investigation into the roles of the 
The protected areas: are they still in the 'pleasure periphery' or are they destinations for sustainable tourism activities?

nature-based tour leader. Tourism Yoon, Y., \& Uysal, M. (2005). An examination Management, 14(1), 91-98. of the effects of motivation and

Whitelaw, P. A., King, B. E. M., \& Tolkach, D. (2014). Protected areas, conservation and tourism - financing the sustainable dream. Journal of Sustainable Tourism, 22(4), 584-603.

Williams, S. (2000). Tourism geography. London: Routledge. satisfaction on destination loyalty: a structural model. Tourism Management 26(1), 45-56.

Young, J., Richards, C., Fischer, A., Halada, L., Kull, T., Kuzniar, A., \& Watt, A. (2007). Conflicts between biodiversity conservation and human activities in the central and Eastern European countries. Ambio, 36(7), 545-550. 